of looking at the problem, suggested different solutions. The academics recommended harder recruiting and higher salaries, but the industrialists suggested darkly that far too many graduates are going on to do doctorates and that many of them are not worth recruiting anyway. Dr. Finniston said that industry really does not need enormous numbers of outstanding physicists - they tended to get in cach other's way. At his own establishment, he said, only a dozen of the staff of 500 are absolutely top men.

\section{Cars for Posterity?}

IT looks like being some time before any city can boast of enough electric cars to make a traffic jam. At the symposium on the subject organized by the Institution of Electrical Engineers last week, there was plenty of enthusiasm among town planners, battery manufacturers and ordinary inventors, but at the end of the day the petroleum companies cannot have been seriously alarmed. Many of them, in any case, have been hedging diligently on fuel cells and batteries, and one was even magnanimous enough to lend space on the South Bank in London for an exhibition of electric prototypes as part of the symposium.

The immediate problem is to design an electrical system which is light enough for its performance to match realistic needs. Given that it needs something like $0 \cdot 25 \mathrm{kWh}$ to move a vehicle with a gross weight of 1,000 lb. a distance of a mile at 30 m.p.h., it is not surprising that designers have long since washed their hands of the lead acid battery. At 60-100 lb. per $\mathrm{kWh}$, it is altogether too heavy. But even the silverzinc battery, useful enough in satcllites, is at once too heavy and not long-lasting enough. This is why interest in storage batteries as such has shifted to electrical cells based on much more exotic-and potentially hazardous-chemical reactions. A battery based on the reaction

$$
2 \mathrm{Na}+5 \mathrm{~S} \rightleftarrows \mathrm{Na}_{2} \mathrm{~S}_{5}
$$

is being developed by the Ford Motor Company in the United States, and was described to the symposium last week. Just over a pound of battery would be enough to propel a small vehicle for a mile, but the battery would have to operate at roughly $600^{\circ} \mathrm{C}$, so that all kinds of technical and even administrative problems may have to be dealt with before it appears on the streets.

Batteries which are essentially reversible fuel cells seem to be a more practical proposition. Cells based on the interaction of zinc with oxygen (which is as free as air) may be made to weigh three or four pounds for each $\mathrm{kWh}$ they store, but in practice there are likely to be problems because of the strong solution of potassium hydroxide in which the zine clectrodes would have to be immersed. A fuel cell able to operate successfully on natural gas and air would probably have a cheerful future, but it was plain, at the symposium last week, that the success of electric cars may depend not on better batteries but on more efficient ways of using electricity for traction. A simple device for regenerative braking would be a great boon, for example. And, of course, discrimination against internal combustion engines on the grounds of air pollution would have an even more decisive influence.

\section{Jam Tomorrow}

"Computring in the seventies will consist entirely of what we were promised in the sixties." This was the resigned conclusion of one participant after the conference organized last wcek by the Manchester and District Branch of the British Computer Society, which discussed the possible developments of computing a decade from now. The comment was made after a presentation which made production control by computer-a development promised almost daily since the first card was punched-seem infinitely distant and appallingly complicated, but it could also apply to other developments. Multiple access, character rccognition, machine translation and the development of universal computer languages have all failed to live up to expectations.

The computer men at the conference spent little time discussing their failures, however. There was some refreshingly trenchant criticism of the actions of the government in the data processing field. One delegate said that the "interference" of the National Computing Centre, the National Research Development Corporation and the General Post Office in data processing was a waste of time, a squandering of resources and a dissipation of effort. It is hardly necessary to add that he represented a computer bureau. The bureaux have expressed alarm over government actions, particularly the National Data Processing Service to be run by the GPO. They fear that the service will be run inefficiently and supported by hidden subsidies from other postal services. More cynically, they suspect the GPO of trying to sell off spare machine capacity in the lucrative bureau business, which some forecasts believe will reach $£ 30-£ 40$ million per year in Britain. At present there are 50 bureaux, the vast majority in London, and it is agreed that, with or without the GPO, some rationalization is inevitable. Ultimately there will be perhaps 5 or 6 bureaux, offering a wide range of services. One danger of the GPO plan was mentioned half seriously by Professor Gordon Black, Director of the National Computing Centre: if the service is run in conjunction with the new Giro system, how will dishonest users be prevented from gaining access to commercial secrets ?

\section{Co-operative Biologists}

ThE International Biological Programme swings into full scalc action in July this year, after three years of planning. About forty countries are co-operating by organizing their own national committees, and the plan of action of the British committee was published last week. It includes some 150 projects being carried out in Britain and in collaboration with other countries.

The whole programme is divided into seven sections, covering productivity of land and the adaptability of human beings. Of the British contribution to the programme, 14 projects are being carried out overseas; they include productivity studies of a lake in Uganda, and a comparative study of British, Indian and inshore waters. Human adaptability is being studied at high altitudes in Ethiopia and Bhutan, and at more normal levels in New Guinea; the productivity of rain forest in Malaya and savannah in Uganda is being investigated. Of the investigations nearer home, most would have been carried out even if the programme had not 